\title{
ARE BANKING SYSTEMS IN EAST ASIA STRONGER?
}

\author{
Philip Turner*
}

Bank for International Settlements

\begin{abstract}
The Asian financial crisis was severe because local banking systems were weak. The major policy effort to improve supervision and strengthen banking systems that followed has achieved substantial results. But these achievements have been somewhat uneven across the region. The current favourable environment should not lull governments into complacency: new risks are arising and continued reforms are needed.
\end{abstract}

Keywords: Asian financial crisis, risk management, bank supervision, bank balance sheets.

Suggested Running Title: Are Banking Systems Stronger?

* $\quad$ CH-4002, Basel, Switzerland. Phone: +4161280 8428. Fax: $\quad+41612809100$. Email: Philip.Turner@bis.org 


\section{Introduction}

The Asian financial crisis was caused by the combination of banking system weakness, poor macroeconomic policies and a massive shock. The main common elements of bank weakness were:

- $\quad$ Banks had poor risk management procedures and supervisory oversight was lax;

- $\quad$ The governance of state-owned banks was unsatisfactory and the private sector system was fragmented and uncompetitive;

- Banks were undercapitalised and provision for non-performing loans (NPLs) inadequate;

- $\quad$ Rigid exchange rate policies led to complacency about exchange rate risks;

- $\quad$ Financial data provided by banks were misleading, undermining market discipline.

The crisis therefore served to focus attention on the need to strengthen banking systems: this paper examines how far this has been achieved.

Almost all the standard statistical indicators suggest that banking systems in East Asia have become much stronger since the crisis. While this improvement is partly cyclical, the underlying resilience of banking systems has improved. The argument of the paper can be briefly summarised. The macroeconomy is at present unusually favourable to banks, but new risks are being created. These will require different risk-assessment capabilities than were needed before the Asian crisis. Major structural change and reforms have largely restored the financial intermediation function of banks. An important new trend has been the shift of bank lending from business to households. Nurtured by much better official supervision, the quality of risk management by banks has improved although shortcomings remain (including in the markets and legal environment in which banks operate).

\section{Favourable macroeconomy environment but new risks}

The first key macroeconomic aspect is greater stability: strong growth and lower inflation. Much reduced macroeconomic volatility has also helped the banks. Real policy rates fell steadily after early 1999 and now close to zero, which is unusual for rapidly growing countries. ${ }^{1}$ The positive spread between the yield on long-term paper and short-term rates has boosted banks' profits; falling long-term interest rates generated capital gains on bond holdings.

1 See Graph X in Ito (2007). Average real policy rates over the $1986-2005$ period were as follows: $5.8 \%$ in Indonesia; $4.8 \%$ in Korea; $2.4 \%$ in Malaysia; $4.7 \%$ in the Philippines and 3.5\% in Thailand. 
The second aspect is that several countries now have large current account surpluses and have built up high levels of foreign reserves. Exchange rate appreciation has been resisted: with the exception of Korea, real effective exchange rates are now lower than at the beginning of the decade. The scale of reserves accumulation in some countries has been very large relative to most standard measures of the size of the financial system such as M1, domestic credit and public debt securities outstanding, and this has inflated the balance sheets of the central bank and the banking system. Much of the paper issued to finance reserves acquisition has been absorbed by the banks (Mohanty and Turner, 2006). As a result, banks have become much more liquid: the danger of this is that the lending response to improved economic conditions could be strong and difficult to control.

\section{Structural change}

Because many non-financial enterprises became unable to service their debts during the crisis, policies of corporate restructuring and reform were crucial. The effectiveness of such policies are discussed in other papers in this volume: see in particular Lee and Rhee (2007). It suffices here just to note that corporate reforms and banking sector reforms are mutually dependent. How governments addressed the bad debts on the books of the banks is not covered in this paper; earlier analysis suggests that success depends on the early commitment of substantial fiscal resources to deal with bad loans and on effective measures to strengthen supervisory oversight (Hawkins and Turner (1999), Fung et al (2004)).

The aspect of particular relevance for this paper is how far the structural shortcomings of East Asian banking systems have been addressed. The picture here is rather mixed. Some countries have pushed radical change while others have adopted a more evolutionary approach. The following paragraphs summarise the main elements of change: reforming state banks; consolidation; and the greater role of foreign banks.

\section{(a) State control, corporatisation and privatisation}

Banking systems that are dominated by state-owned banks (SOBs) tend to be less efficient than systems where private sector banks are subject to competition and effective shareholder discipline. Moreover, political interference can undermine the independence of lending decisions, and the danger of regulatory forbearance is greater. Nevertheless, SOBs probably have a useful part to play in developing countries, especially where the private sector banks have a narrow shareholder base (wealthy families, non-financial firms etc) provided they operate under effective governance arrangements (Reddy, 2002).

SOBs accounted for a significant share of total bank lending before the crisis, and the governance of such banks was often not transparent. The crisis increased the role of the 
State as governments nationalised some banks or used public sector banks to take over the remnants of private sector banks (Hanson, 2005). Reversing this nationalisation has taken time but has nevertheless progressed. In several cases, however, there is still a residual state ownership which can be used to undermine the effective running of a bank: see Nasution's comment. Sussangkarn and Vichyanond (2007) explain how a rapid expansion in lending by public financial institutions to small-scale borrowers followed by debt forgiveness could undermine market discipline.

Privatisation was slow because the value of bank assets was depressed by the recession and because it was difficult to find reliable domestic investors. Given this, one radical approach deserves a mention. Faced with limited interest from the major international banks, Korea sold two of its banks to foreign non-bank private equity investors. These institutions were not committed to running banks over the medium term but did have a strong shareholder focus, which entailed a short-term plan of restructuring and then reselling. Foreign investors bargained hard for low prices, and the government had to brave domestic criticism as it sold commercial banks to foreign institutions. While the foreign owners pushed hard to improve efficiency, Lee and Rhee (2007), argue that these banks did not get deeply involved in the difficult medium-term tasks of "rejuvenating" ailing companies through restructuring.

On balance, then, the state-owned sector has shrunk but is still larger in East Asia than is optimal. Where there is a case for maintaining SOBs to serve public policy purposes (eg financing poor farmers), governance arrangements need to ensure better accountability. In some cases, the behaviour of newly privatised banks may have been blunted by the retention of a "golden share" that gives the government an effective veto. Nevertheless, the rationalisations that followed in several privatised firms is evidence that banks did become more efficient. However, a review by Mihaljek (2006) found no decisive evidence that private sector banks performed better than state-owned banks in the years following the crisis. Finding that the standard prudential and efficiency indicators for banks improved across the board, he concluded that increased competition provided all types of banks with strong incentives to improve performance.

\section{(b) Consolidation}

In most Asian countries, the banking system included many smaller banks that were family-owned and operated regionally. Such banks were often not competitive, and backward in their use of modern technology. There were two other failings. The first failing was the lack of external market discipline since such banks were either not listed on the local stock exchange or had share ownership concentrated in a few hands. The incentives for 
shareholder oversight were thereby weakened and the threat of takeover - the usual impetus for mergers - did not exist. Many more Asian banks are now listed on stock exchanges than was the case in the mid-1990s. But shortcomings remain. Nasution in his comment explains that the government still appoints the management of certain listed but state-controlled banks in Indonesia. Guinigundo (2006), notes that only universal and commercial banks in the Philippines are required to have their stocks offered in public, and only $10 \%$ of their minimum capital must be listed.

The second failing was the prevalence of connected lending, often because powerful families controlled both banks and non-financial enterprises. Connected lending undermines not only independent credit risk assessment, but also diversification of credit risks (especially in the absence of credit risk transfer mechanisms). Malaysia forbids lending to related parties or controlling interests. In Korea, much tighter limits on lending to corporations have been imposed.

The authorities in some Asian countries actively used the crisis to promote mergers that were in any case needed. Malaysia provides a good example of comparatively fast government-led consolidation. By 2002, the country had consolidated 71 institutions to 30 domestic institutions organised in 10 domestic banking groups. The fiscal costs of restructuring were held below 5\% of gross national product (GNP): Zamani (2006) attributes this achievement to "the timely, prompt and holistic approach ... that prevented an adverse situation from worsening further". In other cases, government-led consolidation efforts still continue, sometimes guided by a Financial Sector Master Plan. Watanagase et al (2006), describe such a five to ten-year development plan for Thailand, which aims to reduce the number of small players and eliminate regulatory arbitrage. In order to encourage small banks to merge, most countries have also raised minimum capital levels for the award of a banking licence.

The past decade has seen a wave of mergers between domestic firms in Korea, Malaysia, Thailand and the Philippines (Table 4 in Turner, 2006); but there has been much less merger activity in Indonesia. An important constraint is that small banks tend to be owned by families who are very reluctant to give up ownership (Goeltom (2006), Guinigundo (2006)).

The market share of the largest banks has risen in all countries (Table 1), but consolidation has not undermined market competition among domestic banks. Kim et al (2006) note that such competition is fierce; but they also note that the authorities intend to keep "a close eye on significant changes in the financial landscape brought about by ... the birth of megabanks ...". Another word of caution echoed at the conference was that "bigger is not necessarily 
better": smaller banks often survived the crisis better than larger ones and that governments should not determine the "correct" number of banks in the system.

\section{The greater role of foreign banks}

The third major change has been the greater role of foreign banks. There are two sources of information about this trend. One is the Bank for International Settlements (BIS) banking statistics and the other is data on ownership. Lending by international banks to borrowers in developing Asia has doubled since the end of 2000: see Table 2. Increased lending has been driven by US and European (especially UK) banks. The greatest expansion has been in Korea; but lending to entities in Indonesia and Thailand is still less than it was in the mid-1990s. A large proportion of the recent surge in international bank credit has taken the form of lending in local currency. Before the Asian crisis, by contrast, lending was denominated in foreign currency (panel B in Table 2), so that borrowers were burnt badly when exchange rates collapsed. Much of this was borrowing by Asian banks in the international interbank market: BIS statistics show that during 1995 and much of 1996, interbank borrowing by banks in the five countries was running at an annual rate of more than $\$ 40$ billion.

Although foreign ownership of banks in Asia has risen, and strategic minority investments by foreign firms have been significant, foreign banks have made fewer inroads than in some other emerging markets (Turner, 2006). Nevertheless, the foreign-owned banks have probably helped to improve the risk management practices of domestic banks and look beyond collateral-based banking. They introduced new techniques of credit assessment (eg credit scoring), and often spearheaded the expansion of retail business - which was long neglected in much of Asia. Foreign banks also brought new technology as well as easier access to capital and new financial instruments. Foreign banks can enhance resilience either by lending countercyclically after a crisis (there is some evidence of this in Korea) or by acting as a "safe haven" for local foreign currency deposits, and so limiting the size of outflows to foreign institutions based abroad. ${ }^{2}$

A recent review by the BIS's Committee on the Global Financial System (CGFS, 2005) broadly confirmed these benefits. Nevertheless, some drawbacks were also identified. One was that the reliance on quantitative or standardised information for loan extension created a preference for lending to households rather than to SMEs, which typically required more

2 Detragiache and Gupta (2004) find that Asia-oriented foreign banks were less destabilising during the crisis than non-Asia-oriented banks. 
local, "soft" information. Kim et al (2006) echo this feeling in the case of Korea; but there are counterexamples as Nasution in his comment on this paper points out. A second risk is of excessive centralisation. The interests of the shareholders of the parent bank might require curbing the activities of the individual subsidiary - and that might go against host country interests. A third drawback could be the delisting of the subsidiary from the local stock exchange, which can undermine market discipline.

\section{Measures of the performance}

The Asian crisis demonstrated that it is very difficult for outside observers to have an accurate picture of the health of a country's banking system. Any search for a single, comprehensive indicator is fruitless because each single indicator has shortcomings; it is better to consider as many indicators as possible, and the following paragraphs examine the indicators commonly used.

\section{(a) Contribution to financial intermediation}

A key function of a banking system is to intermediate credit to the private sector. Taking deposits from the public to invest in government bonds (or lend to state-owned enterprises), but does not advance financial intermediation in the private sector. How did the crisis affect the performance of this function?

One approach is to examine quantities of credit extended. The crisis led to a sharp contraction of bank credit to the private sector in Indonesia, Malaysia and Thailand (Figure 1) - declines that were much greater than those seen after banking crises in industrial countries. There has been a steady decline in the Philippines, because of weak demand and the continued high level of NPLs on the books of the banks. There was no similar decline in Korea: the main reason for this is a shrinkage in non-bank intermediation. ${ }^{3}$ By 2003 or 2004, however, this shrinkage of bank credit in East Asia as whole seems to have ended. Mohanty et al (2006) find clear evidence that bank credit recovered more strongly in the post-crisis period when policies to get NPLs off the balance sheets of banks had succeeded. Nier and Zicchino (2005) reach a similar conclusion.

Another approach is to look at the pricing of bank credit. In the years that followed the immediate aftermath of the crisis, policy rates were steadily reduced but bank lending rates

3 Loans made by banks accounted for more than $70 \%$ of the total loans in the financial market at the end of 2004 , compared with only $40 \%$ at the end of 1997 . The main reason was that Korea's massive financial restructuring entailed guarantees for bank deposits and substantial assistance to banks, which could therefore attract funds. See Kim et al (2006). 
were at first held up as banks sought to rebuild profits. A simple econometric test reported in Turner (2006) suggests that there was indeed a significant drag in during the period 199802: less than half of the change in the money market rate had been passed through to banks' lending rates within 12 months. By the 2003-06 period, however, the pass-through had risen significantly as the health of the banks had improved.

\section{(b) Banks' income statement and balance sheet variables}

The quality of balance sheet data has improved beyond recognition since the mid-1990s. Regulators have put increasing pressure on banks to publish comprehensive balance sheet data, subject to more rigorous auditing and increasingly according to international standards. This has often been supported by stronger rules on corporate governance, including the creation of compliance officers to ensure that accounting rules are properly followed.

The collection of such data by Fitch's Bankscope has helped outsiders get snapshots of banking systems that were not available in the mid-1990s. The regular publication of key financial soundness indicators in the IMF's Global Financial Stability Report ensures that such data are widely available. One caveat, however, is that new ownership patterns create significant discontinuities in some income and balance sheet data (and in equity prices too).

A natural starting point for analysis is profitability. Table 3 shows that profits have recovered across the board from the depressed levels immediately after the Asian crisis. The profitability of Asian banks before the crisis was low: the average rate of return on assets in the first half of the 1990 s was only $0.7 \%$ in Indonesia and Thailand, and, $0.6 \%$ in Korea. Current measured profitability is higher and - assuming that accounting standards have become much more rigorous - the underlying improvement is still larger. Nevertheless, part of the strong profit performance in the past two to three years reflects short-term capital gains (on bonds as interest rates fell) that at best are unlikely to recur. In this context it is notable that the data on net interest margins are more ambiguous. Such margins have widened significantly in the case of Korea, where they were comparatively low in the mid-1990s, and Indonesia but not elsewhere. These margins are much lower than in other emerging market countries.

Most countries have substantially reduced the NPLs carried on the books of the banks (Table 4). Nevertheless, at end-2005 NPLs were still high in Indonesia and the Philippines. The practice of "evergreening" loans has been reduced, but probably continues to lead to some understatement of NPLs in some countries. Note, however, that NPLs are often concentrated in one or two banks so that they are not representative of the banking system as a whole. In some cases, a massive rise in the reported NPLs of a bank will reflect the (overdue) recognition of existing problems - and in this sense represents an improvement. 
Measured in terms of operating costs, banks in Korea and Malaysia seem to be the most efficient, with Thailand a close third (Table 5). However, there is no evidence of any dramatic improvement in efficiency - at least on this aggregate measure - over the past decade. Given the scale of the crisis, this is surprising. The cost/income percentages computed by The Banker magazine as a gauge of efficiency are usually below $60 \%$ in industrial counties with efficient banks. The banks in Korea, Malaysia and Thailand have cost/income percentages below this threshold; but that of the Philippines is substantially above. ${ }^{4}$ Little evidence of major efficiency gains is reported. This may reflect a changing customer base (reduced lending to large borrowers - corporations or governments). Another interpretation is that mergers and consolidation have not actually reduced excess capacity and that restrictive labour practices continue to impede productivity improvements. ${ }^{5}$

Risk-adjusted capital ratios have risen to well above the regulatory minimum (Table 3 ). In 1995, the risk-adjusted capital ratios were below those in the United States. What is even more remarkable is that the standards for regulatory capital have become more rigorous, and more in line with the international framework for capital devised by the Basel Committee on Banking Supervision (Villar, 2006). Nevertheless, the capital of some banks includes non-tradable government recapitalisation bonds, carried on the balance sheet at prices which may involve an overvaluation of capital.

A further weakness of income and balance sheet variables is that they are dependent on cyclical conditions. Banks do better when growth is strong, policy rates low, equity and bond prices rising and the yield curve upward sloping. Virtually all these elements have been present in Asia in the past few years - which means that current income and balance sheet variables overstate how well Asian banks are really doing. One preliminary way of exploring this is to use the annual data for the larger banks summarised by Fitch Ratings over a decade to estimate the sensitivity of net profits before tax to some standard macroeconomic variables. The results were remarkably consistent across the four Asian countries. Stronger growth boosts bank profits in all countries except the Philippines. Higher real short-term interest rates depress profits everywhere except in Malaysia (Table 12 in Turner, 2006). The pooled estimates for all countries shown in Table 6 suggest two important implications. One, a 1 percentage point decline in the growth rate reduces profits before tax by 23 basis points. The second is that a 1 percentage point rise in the real one-month interest rate (passed through the yield curve) reduces profits by 26 basis points. Surprisingly, the sign on the yield

\footnotetext{
4 The percentages are: Korea 53\%; Malaysia 44\%; the Philippines 64\%; and Thailand 54\%.

5 See "Two stories across the globe", Euromoney, August 2006.
} 
spread is the opposite to that expected. The nature of the link between real interest rates and bank profits is complex and clearly deserves further exploration. More refined cross-country econometric work on the cyclical adjustment of key ratios drawn from banks' income and balance sheet statements would be useful. Guinigundo (2006) notes that econometric methods are used in the Philippines to produce a one-year-ahead forecast of bank solvency from banks' financial data and from macroeconomic data.

\section{(c) Market indicators}

Information from markets can provide forward-looking evidence about the health of banks, but the usual caveats apply with even greater force in the context of emerging markets: the listed banks may not be representative of the banking system as a whole (eg a weak state-owned bank will not be listed); and market prices may over-react to transient changes (Moreno, 2006). Market indicators include: spreads a bank pays in the interbank market; spreads on long-term bonds it has issued; and equity prices. This section concentrates on bank share prices, a readily available source of useful information for a large number of countries, which have often indicated problems before the regulators found them (Pettway, 1980).

How effectively shareholders can monitor banks depends on the quality of disclosure; and share prices can be contaminated by expectations that banks will not be allowed to fail. Rochet (2005) summarises evidence that market indicators do contain "news" that is additional to regulatory information. Yet market signals can also mislead. Hoggarth et al (2003), for instance, find that market indicators for UK banks generate many "false positives" (ie sharp fall but no subsequent crisis). This and similar studies counsel against placing exclusive weight on market indicators.

The level of bank share prices presumably reflects the market's assessment of future profits, a useful proxy for the performance of banks. The real level of bank share prices has risen strongly only in Korea after a collapse in the late 1990s: see Figure 2. Share prices remained depressed in 2005 in Indonesia and, to a lesser extent, the Philippines.

In addition, the volatility of bank share prices can be interpreted as a measure of the riskiness of banks and can be a powerful predictor of crises. Over the period 1995 to 2000, the volatility of bank share prices in Asia was far greater than that of banks in the major industrial countries. Since 2001, however, the gap has narrowed (Turner, 2006). The main 
exception is Indonesia, where bank share prices have remained volatile. Hence markets perceive that the riskiness of banks has indeed fallen in most of these countries.

An important recent development has been to use option pricing theory ${ }^{6}$ to combine data on the equity market value of a bank, the volatility of equity prices and the value of the bank's liabilities to obtain a probability distribution of the bank's assets-to-liabilities ratio. This yields an implied probability of default, and a so-called "distance-to-default" ratio which indicates the number of standard deviations from the default point. The IMF has recently applied this technique to banks in Asian emerging markets: see the various reports issues of the Global Financial Stability Report. Their calculations show a considerable improvement in distance-to-default measures for Asian banks since 2003. Sweden's Riksbank has computed such ratios for its banks, publishing distance-to-default ratios for each bank but without naming the individual banks (Persson and Blåvarg, 2003).

\section{(d) Macro indicators}

Macroeconomic indicators can also capture vulnerabilities of the banking system as whole. Such indicators can be based on prices (eg costs of funding) and on quantities (eg the rate of credit expansion, sources of funding etc). One such summary indicator was developed about a decade ago at the BIS in order to capture the key ingredients of banking crises in emerging economies: the speed of credit expansion; the degree to which local lending was financed by borrowing from international banks; and the real short-term interest rate (Hawkins and Klau, 2000). This indicator has fallen sharply in recent years and is now rather low. Another indicator is the exposure of banks to foreign currency risk, not necessarily directly (mismatches on the books of the banks) but also indirectly due to credit risks (because borrowers have currency mismatches). An important element of the Asian crisis was that substantial (and unexpected) currency depreciation hurt the creditworthiness of private borrowers who had taken loans in dollars. Goeltom (2006), for instance, notes that the NPL ratios of Indonesian banks for foreign currency credits greatly exceeded that of credits drawn in rupiah. In general, the dollarisation of local banking systems has been reduced since the crisis. One important exception is the Philippines, where foreign currency deposits still constitute about one-third of total deposits with the local banks. There have, however, been recent signs that certain borrowers in some Asian countries have been increasing their borrowing in foreign currencies. Low foreign interest rates and expectations that the local

\footnotetext{
6 According to this approach, the market value of a bank's equity is regarded as a call option on the bank's assets, struck at the book value of its liabilities.
} 
currency will appreciate inevitably create incentives to borrow in foreign currencies, and the Korean authorities have recently urged banks to curb yen-denominated loans.

\section{Assessment of ratings agencies}

The major ratings agencies can complement public financial statements with in-depth reviews of particular banks. The first major indicator is Moody's Bank Financial Strength Rating ("BFSR"). This grades the intrinsic financial strength of a bank on a scale from $A$ (exceptional) to $E$ (very weak) without allowing for external credit support (eg from the government or the parent) but taking into account other risk factors in the bank's operating environment, including the macroeconomic state of the economy, the fragility of the financial system, and the quality of banking regulation and supervision. The second indicator is Fitch's Individual Rating, which also assesses the bank's intrinsic financial strength.

Users of these indicators must remember that ratings agencies put a premium on rating stability (to help "buy and hold" investors), rather than constantly adjusting ratings as new information emerges. Because they are cautious in granting upgrades only on the basis of good performance during a cyclically favourable period, their ratings adjust to improvements in underlying strength only slowly, which is relevant to the recent period.

Moody's BFSR ratings of banking systems in Korea, Indonesia, Malaysia and Thailand in March 1997, just three months before the crisis, were not strong but did not fully capture the disaster that was to follow (and were not much different than what they had been in 1995, Table 7). Only after the crisis had broken - by December 1998 - were they downgraded. By December 2005, however, the banking systems in all five countries had been upgraded significantly, but the ratings suggest that significant weaknesses remain (although this may reflect the understandable conservatism about upgrading). However, Fitch, but not Moody's, has Korea and Malaysia on a par with the banking system in Germany.

\section{Assessing risk exposures}

Many of the indicators above (the main exceptions being equity prices and ratings) share a common shortcoming - they relate to the past. This section looks at future risks.

\section{(a) Increased lending to households}

Any very rapid expansion into a new area of business raises questions about banks' ability to assess unfamiliar risks. The main new development over the past five years have been the substantial shift of bank lending from businesses to households, particularly marked in Korea and Thailand (Table 8). 
There are several grounds for comfort with this new trend. The first is that it reflects the removal of restrictions on lending to households, which widens choices available to households, and helps banks to diversify their loan book, which was often too dependent on lending to large companies. Secondly, more households have become eligible for mortgages thanks to more flexible mortgage contracts. The comparatively low ratio of mortgage debt to GDP in these economies suggests considerable room for mortgage lending to expand. The low exposure of banks to mortgages in Indonesia and the Philippines probably means that banks in these countries would also do well to diversify into increased mortgage lending (MAS, 2006). Default rates generally on mortgages have remained low, and regulators have encouraged banks to apply conservative loan-to-value ratios.

Perhaps more worrying is unsecured lending to households - led by finance companies willing to take more risks than banks, or to underprice such risks (and perhaps putting regulated banks under some pressure also to underprice). The credit card debacle in Korea is best known. With many credit providers competing for business, an individual lender would have only limited information about the total exposure of their clients. One response to this lack of information has been to establish credit bureaux, encouraging lenders to overcome natural reluctance to "share information with competitors".

Perhaps the greatest inherent risk is that first-time household borrowers may not understand the risks they are assuming - to higher interest rates, to a decline in property prices, to cyclical income reductions and so on. In some countries, efforts have been made to educate households about such risks and to ensure information about loans is offered in a simple and accurate way (Zamani, 2006). Another set of risks may be legal - relating to the cost of the legal enforcement of collateral claims.

A recent BIS survey asked central banks to assess the probability of significant harm to the financial sector from 11 different shocks. Their conclusion was that the financial sector's vulnerability to external shocks was comparatively low - less than 10 years ago. But the vulnerability to domestic shocks (eg domestic demand, domestic interest rates and local property prices) was rather high - and indeed significantly higher than a decade ago (Moreno, 2006). 
The costs of recapitalising banks, fiscal deficits and large-scale foreign exchange intervention have increased gross public debt issuance. ${ }^{7}$ The banks have ended up as holders of much of this debt, which is mainly short-term, but there are also sizable exposures to interest rate risk from increased holdings of long-term paper. Paradoxically, banks in countries where the sovereign credit risk is worse - and credit spreads fattest - earn more on their holdings of government bonds and face the greatest risks. If banks are not obliged to mark-to-market their holdings of government paper, unrealised losses may not be registered in the accounts of the bank.

Indirect interest rate risk (due to potential credit risks due to lending to heavily indebted borrowers) seems to have been reduced. Strong profits and reduced borrowing have enabled the non-financial corporate sector in most countries to reduce debt/equity ratios. Korea's debt/equity ratio, to cite one dramatic change, has gone from $56 \%$ in 2001 to $27 \%$ by the end of 2005. In most cases, corporate interest rate coverage ratios have also risen. ${ }^{8}$ The main exception to this favourable change is Indonesia. After a substantial rise in debt/equity ratios during the past five years, the interest coverage ratio is low which means that firms are vulnerable to higher interest rates.

\section{(c) Exchange rate risk}

Direct exchange rate risk (ie that held directly on the books of the bank) has probably been contained. But it is not clear that enough attention has been paid to indirect currency risk, namely credit risks that would materialise when borrowers are faced with a large exchange rate movement.

The nature of the exchange rate risk that now confronts East Asia is exactly the opposite to the depreciation shock that hit them in 1997/98. Current account surpluses and substantial foreign exchange assets mean that East Asia could at some point face a large exchange rate appreciation, which would hurt the tradable good sector. It is not clear that this risk is being given the attention it deserves - perhaps on the assumption that countries can easily limit

7 A simple approximation is deposit money banks' claims on the monetary authorities and on government. As a percentage of GDP, this has increased substantially in recent years:

$\begin{array}{lccccc} & \text { Indonesia } & \text { Korea } & \text { Malaysia } & \text { Philippines } & \text { Thailand } \\ 1995 & 1.9 & 5.3 & 5.9 & 9.5 & 2.2 \\ 2005 & 14.8 & 14.9 & 37.6 & 14.5 & 17.1\end{array}$

8 That is, earnings before interest expense and tax dividend by interest paid. See MAS (2006) for details of estimates of the non-financial corporate sector. 
currency appreciation. Goldstein (2005) stresses this risk in his comprehensive attempt to measure the various risks to which emerging market economies are exposed.

\section{Risk management awareness}

A key issue is how well future risks are managed. This issue raises two distinct questions:

- How well do banks manage their risk exposures?

- Do supervisors take a forward-looking approach when assessing the risk management processes of the institutions they regulate?

On the first question, Moreno (2006) finds evidence that the risk management capacities of many banks have improved significantly over the past decade. There is greater awareness of the need to adapt risk management procedures to evolving conditions. One indication of this is the greater use by banks worldwide on quantitative techniques of risk management, including credit scoring to capture the solvency of potential borrowers. Another instance is the creation of credit bureaux, combined with efforts to quantify default history. The shift to mark-to-market accounting and the greater use of data on market volatility to quantify market risks may also help.

Yet improved risk management capacities count for little if the management culture within banks favours business expansion over risk control. Senior central bankers at a recent BIS meeting, however, did note that the boards of banks in almost all their countries were increasingly focusing on quantitative reports in risk exposures that were often prepared by special units independent of portfolio managers and lending officers. And it is not to be forgotten that Basel II has added important international impetus to the strategic objective of nurturing a new, quantitative risk management across the globe.

A development supporting better risk management has been the further development of derivatives markets. It has become easier to hedge market risks, but hedging credit risks remains more difficult. Nonetheless, private corporate debt markets are beginning to develop. However, the securitisation of credit risks has been limited. Credit default swap markets which can help to price loans that are not traded are still underdeveloped. Kim et al (2006) argue that the credit derivatives market in Korea "needs to be galvanised" to help banks manage credit risk more effectively.

The evidence on the second question is stronger: the quality of supervisory oversight has improved. The promulgation by the Basel Committee of the Core Principles of Banking Supervision was a major milestone. Evidence of the greater awareness of risk management issues is the quality of recent Financial Stability Reports of central banks in the region. These 
provide: better and more comprehensive data on the banking system; critical reviews of exposures of banks and other financial institutions to macroeconomic shocks and analysis of risk management strategies in banks. By way of example, Table 9 summarises how two recent reports addressed credit risk, market risk and liquidity risk. Other examples could be cited: for instance, Watanagase et al (2006) report on the macroprudential analyses the Bank of Thailand conducts stress tests to determine how (for example) the ratio of profits to interest expenses in the corporate sector would react to a reversal in the current global environment of very low long term rates.

The practice of monitoring, supported by the discipline of regular publication, reduces the chances of major vulnerabilities going undetected as they had before the Asian crisis. The production of such reports also means that central bank staff regularly discuss risks with their banks - which should raise awareness on both sides. The publication of regular monitoring reports by supervisory agencies also represents good governance. While there is a vast literature of governance arrangements for central banks, there has been relatively little on the governance of financial sector supervisors. One exception is Barth et al (2006), who attempted to quantify supervisory oversight, finding that "giving official supervisors greater powers [does not] enhance bank operations or reduce bank fragility ...". But two major limitations of this study argue against relying too heavily on this conclusion. The first is that their survey questions reveal what the statute books say supervisors can do, but not what has been done in practice. Theory and practice can be very different. For instance, supervisors may have the statutory right to intervene promptly with a problem bank - but in practice politicians could block or delay such action. Indeed, there is often an inverse relationship between quality and quantity because those countries which do not enforce existing regulations tend to be more relaxed about creating new ones. Hence measures based on counting regulations are misleading.

The second limitation is that finding that bank supervisors have not done well in the past does not imply that supervisory systems cannot be made to work well. As Alex Bowen has put it, the constructive question is: "What incentives do financial stability authorities actually face, and can they be improved?" (Rochet, 2005). Regular reports of the kind now widely published in Asia mean that such analyses are open to wider scrutiny - so that supervisors can be held more easily accountable for the quality of their oversight.

Another mechanism to nurture good governance is the Financial Sector Assessment Programs (FSAPs) of the IMF. This initiative was not greeted with universal enthusiasm in Asia when it was launched, and for many years the United States, alone among the G7, has declined to participate. But FSAPs have since proved their worth (see IMF, 2006). 
Willingness to conduct such an exercise and the nature of the subsequent reports are very important indicators of financial system risks.

\section{The quality of governance}

Poor corporate governance, unsatisfactory legal arrangements and lax supervision all contributed to weaknesses in Asian financial systems. While examining these aspects in detail is beyond the scope of this paper, two observations can be made. Although differences of tradition, legal system etc make it impossible to define one ideal system, it is clear that there is now much greater awareness of the importance of governance arrangements. Rules governing the conduct of directors, senior management, risk officers and auditors have been tightened.

The second observation is that there is still a certain reluctance in parts of Asia to "move from a subjective, relationship-based economy to a rules-based economy". ${ }^{9}$ Governance shortcomings are still pervasive, but the wide public acknowledgement of this problem by those responsible for financial sector supervision does engender confidence that this issue is being addressed.

Yet legal arrangements are still unsatisfactory. Although lenders' legal rights in Asia are much better protected than in Latin America, the costs of contract enforcement, are still high - with the exception of Korea. This inevitably constrains the ability of banks to effectively manage risks.

\section{Conclusion}

At the risk of some oversimplification, and there is much diversity across the four countries, seven general conclusions could be offered:

(i) The Asian crisis did stimulate major structural changes in some countries, and there is good evidence of stronger performance. Yet there are still several signs of inefficiency, poor risk management practices and so on. In some countries, the government continues to control large banks where governance and risk management practices are poor. Small, family-owned institutions still resist consolidation.

9 The quotation is from Sheng (2006). Goeltom (2006) notes, in the case of Indonesia, that "the lack of understanding with regard to the importance of transparency has created a business environment that does not promote adherence to good governance. To make matters worse, legal enforcement has been virtually absent ... with bankruptcy resolutions being insufficient". 
(ii) The amount and quality of public information now available about East Asian banks is better than it was before the crisis. However, a lack of markets (eg of credit derivatives) makes it hard to price some exposures.

(iii) Income and balance sheet data of banks suggest that banking systems are generally much healthier. Where the legacy of NPLs has largely been dealt with, banks have been able to support strong economic growth. Much of this transformation, however, can be attributed to favourable macroeconomic conditions.

(iv) Market data from the share prices of banks confirm that the sharp declines in the equity value of banks in the three years following the crisis have ended. Further analysis of market data is needed: researchers could combine data on equity prices and volatility with balance sheet data to construct distance-to-default measures for all major institutions.

(v) Assessments of risk exposures in central bank financial stability reviews demonstrate greater awareness of the need for effective risk management in official circles. Ensuring that such awareness is translated into a bank's risk management practices is more challenging.

(vi) Effective risk management by banks also requires supporting infrastructures in the rest of the economy. One element is deep markets to help price and monitor exposures. Another is the impartiality, predictability and speed of legal arrangements. In both areas, East Asia still has much progress to make.

(vii) The essential symbiosis between market discipline and official oversight could be strengthened.

A final word of caution is that Asia's banks now face new challenges, which include:

_ a rapid rise of unsecured lending to households;

- $\quad$ increased exchange rate risks;

_ $\quad$ interest rate risks due to large holdings of government bonds.

Banks monitor closely the direct market risks on their own balance sheets; but they also need to prepare for the indirect credit risks that might materialise from exposures under certain plausible macroeconomic shocks - even if such shocks are not the most likely scenario in the future. 


\section{Acknowledgement}

This paper reflects my own views, and not necessarily those of the BIS. I am particularly grateful for the suggestions from Colin McKenzie and my discussants: Anwar Nasution and Mitsuhiro Fukao. I have drawn on joint work with Morris Goldstein (which is ongoing). Comments on earlier versions by D. Archer, C. Aylmer, M. Chui, A. Cintura, K. Cordewener, I. Fender, A. García Herrero, J. George, S. Gerlach, S. Grenville, D. Guinigundo, S. Kim, M.S. Mohanty, R. Moreno, A. Sheng, I. Shim, W. Tarisa, G. von Peter and T. Watanagase and A. Zamani are acknowledged with thanks. I am grateful to P. Garcia-Luna, M. Santos and S.-K. Pradhan for statistical work. C. Batts provided excellent secretarial assistance. 


\section{References}

Bank Indonesia (2006). Financial stability review II 2005. No 6.

Bank of Korea (2005). Financial stability report. October.

Barth J.R., Caprio G., Levine R. (2006). Rethinking bank regulation, Cambridge University Press, Cambridge..

Basel Committee on Banking Supervision (1997). Core principles for effective banking supervision. September.

Committee on the Global Financial System (CGFS) (2005). FDI in the financial sector. CGFS Papers no 25.

Caprio G., Hanson J.A., Litan R.E. (eds) (2005), Financial Crises, Brookings Institution, Washington DC.

Detragiache E., Gupta P. (2004). "Foreign banks in emerging market crises: evidence from Malaysia", IMF Working Paper, wp/04/129.

Fung B., George J., Hohl S., Ma G. (2004). Public asset management companies in East Asia. BIS Financial Stability Institute, Occasional Paper no 3.

Goeltom M.S. (2006). “Indonesia's banking industry”, BIS Papers No 28, 243-257.

Goldstein M. (2005). The next emerging market financial crisis. In: Financial Crises, (eds Caprio G, Hanson J.A., Litan R.E.), pp. 121-209. Brookings Institution, Washington DC.

Goldstein M., Turner P. (1996). "Banking crises in emerging economies: origins and policy options". BIS Economic Paper no 46.

Guinigundo D.C. (2006). “The Philippine financial system”, BIS Papers No 28, 295-311.

Hanson J.A. (2005). Post-crisis challenges and risks in East Asia and Latin America. In Financial Crises, (eds Caprio G., Hanson J.A., Litan R.E.), pp. 15-61. Brookings Institution, Washington DC.

Hawkins J., Klau M. (2000). "Measuring potential vulnerabilities in emerging market economies", BIS Working Papers, no 91.

Hawkins J., Turner P. (1999). "Bank restructuring in practice". BIS Policy Papers no 6. August.

Hoggarth G., Jackson P., Nier E. (2003). Market discipline and financial stability. In: The future of domestic capital markets in developing countries. (eds Litan R.E., Pomerleano M., Sundararajan V). Brookings Institution, Washington DC.

International Monetary Fund. Global Financial Stability Report (GFSR). Various issues.

(2006). International Evaluation Office. Report on the Evaluation of the Financial Sector Assessment Program. January.

Ito T. (2007). The Asian currency crisis and the IMF: A comparative and historical analysis after ten years. Asian Economic Policy Review, 2(1), ?-?.

Kim S., Kim J., Ryoo H. (2006). "Restructuring and reforms in the Korean banking industry", BIS Papers No 28, 259-268.

Lee J.W., Rhee C. (2007). Crisis and recovery: What we have learned from Korea. Asian Economic Policy Review, 2(1), ?-?.

Mihaljek D. (2006). "Privatisation, consolidation and the increased role in foreign banks", BIS Papers No 28, 41-65. 
Mohanty M.S., Schnabel G., Garcia-Luna P. (2006). "Banks and aggregate credit", BIS Papers No 28, 11-39.

Mohanty M.S., Turner P. (2006). "Foreign exchange reserve accumulation in emerging markets: what are the domestic implications?", BIS Quarterly Review (September), 39-52.

Monetary Authority of Singapore (MAS) (2004). FSAP Stress Testing: Singapore's experience, MAS Staff Paper no 34. August.

(2006). Financial Stability Review.

Moody's Investors Services (1999). "Rating methodology: bank credit risk in emerging economies".

Moreno R. (2006). "The changing nature of risks facing banks", BIS Papers No 28, 67-98.

Nier E., Zicchino L. (2005). "Bank weakness and bank loan supply". Bank of England, Financial Stability Review. December, 85-90.

Persson M., Blåvarg M. (2003). "The use of market indicators in financial stability analysis". Economic Review 2/2003. Riksbank, 5-28.

Pettway R. (1980). Potential insolvency, market efficiency, and bank regulation of large commercial banks. Journal of Financial and Quantitative Analysis 15(1), 219-236.

Reddy Y.V. (2002). Public sector banks and the governance challenge: the Indian perspective. In: Financial Sector Governance: The Role of the Public and Private Sectors. (eds R. Litan, Pomerleano M., Sundararajan V.), pp. 235-254. Brookings Institution, Washington, DC..

Rochet J.-C. (2005). "Prudential policy" and the subsequent discussion. Monetary and Economic Studies (Bank of Japan) 23(S-1) 93-131.

Sheng A. (2006). "The art of reform", Finance and Development. June, 20-23.

Sussangkarn C., Vichyanond P. (2007). Ten years after the financial crisis in Thailand: What has been learned or not learned? Asian Economic Policy Review, 2(1), ?-?.

Turner P. (2006). "Banking systems in East Asia: 10 years later". Mimeo.

Villar A. (2006). "Is financial stability policy now better placed to prevent systemic banking crises", BIS Papers No 28, 99-122.

Watanagase T., Financial Institutions Policy Group (2006). "Maintaining financial stability. the experience of Thailand", BIS Papers No 28, 347-361.

Zamani A.G. (2006). "Re-engineering the Malaysian financial system to promote sustainable growth", BIS Papers No 28, 269-275. 
Philip Turner 14 November 2006

Figures and tables

ARE BANKING SYSTEMS IN EAST ASIA STRONGER? 
Figure 1 Bank credit to the private sector before and after banking crises ${ }^{1}$ As a percentage of GDP

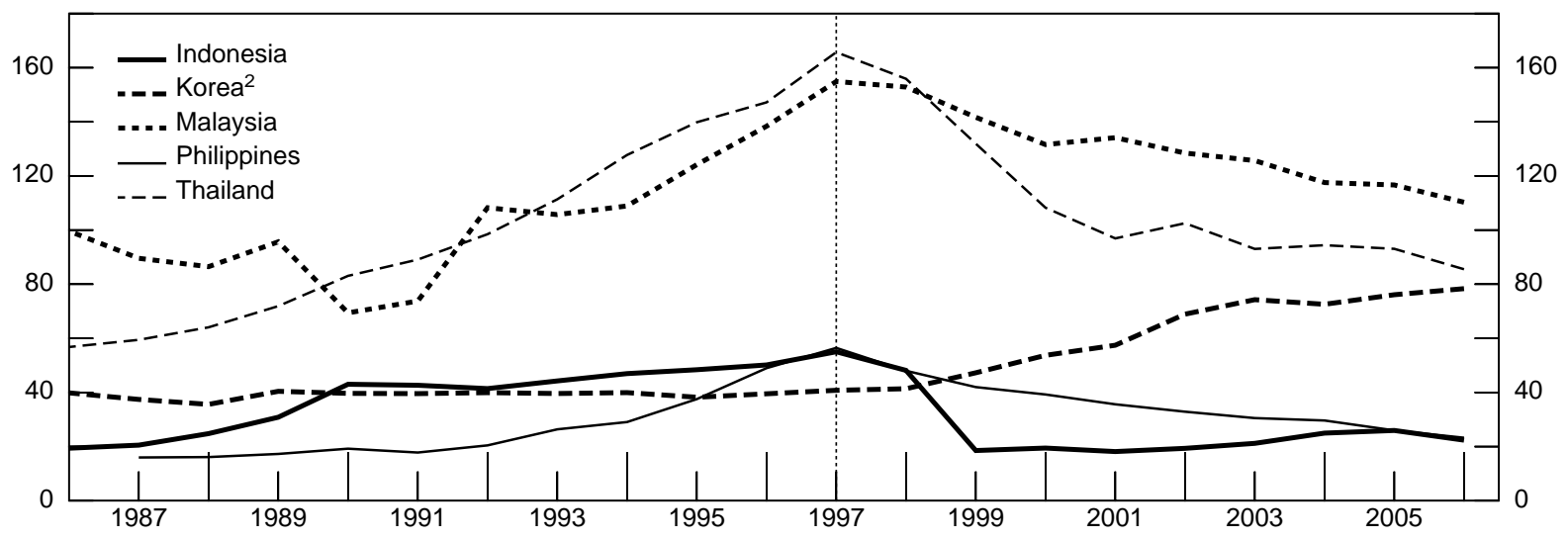

${ }^{1}$ End of period. Data for 2006 refer to second quarter credit data and a GDP estimate. ${ }^{2}$ Total bank loans.

Sources: IMF, International Financial Statistics; IMF, World Economic Outlook; national data. 


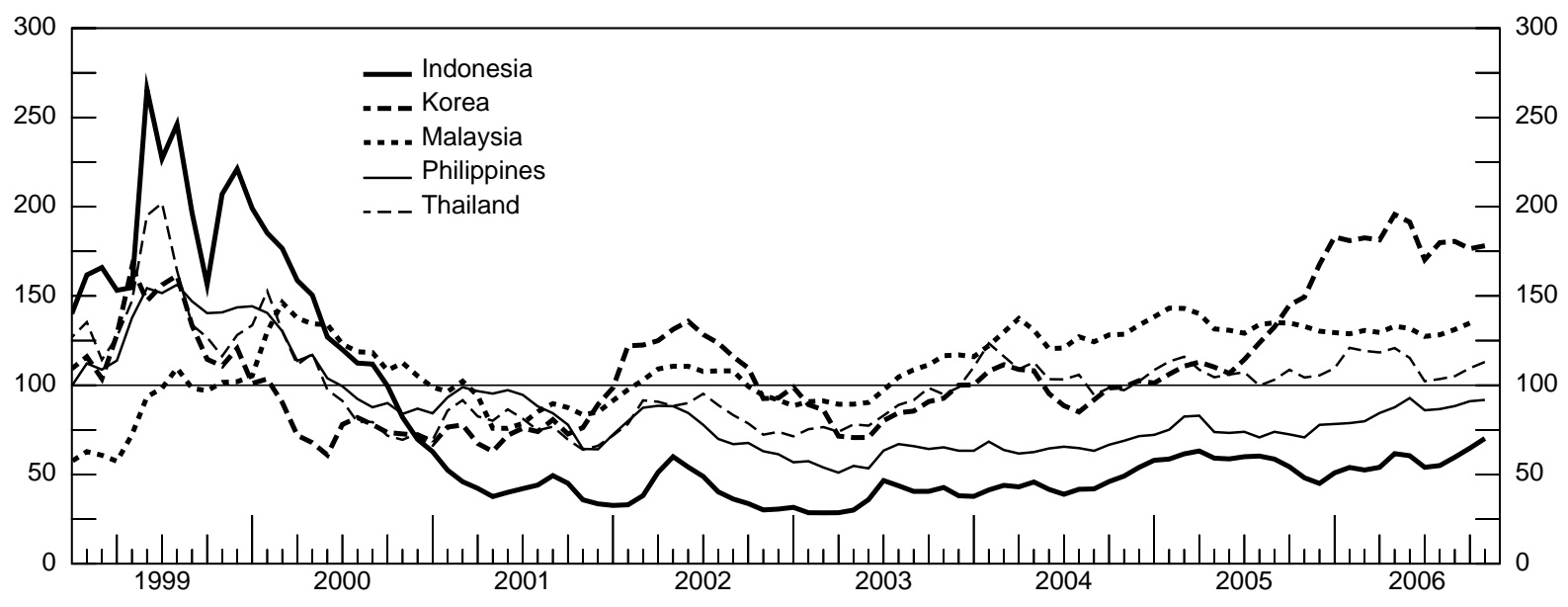

${ }^{1}$ In real terms, deflated by consumer prices; 1999-2002 $=100$.

Sources: Datastream; national data. 
Table 1

\section{Foreign exchange reserves}

\begin{tabular}{l|r|r|r|r|r|r}
\hline & \multicolumn{2}{|c|}{ \% of M1 } & \multicolumn{2}{c|}{ \% of domestic credit } & \multicolumn{2}{c}{ \% of debt securities } \\
\cline { 2 - 7 } & \multicolumn{1}{|c|}{1996} & 2005 & 1996 & 2005 & 1996 & 2005 \\
\hline Korea & 71 & 335 & 5 & 29 & 42 & 99 \\
Malaysia & 97 & 220 & 21 & 41 & 64 & 117 \\
Thailand & 233 & 190 & 15 & 34 &. & 111 \\
\hline
\end{tabular}

Note: The first 2 columns are forex reserves. The other 4 columns are forex reserves less currency in circulation as a \% of the stock of domestic credit and public debt securities. These calculations are an update of Mohanty and Turner (2005).

Sources: IMF; national data. 
Table 3

Bank credit to the private sector

\begin{tabular}{|c|c|c|c|c|c|c|c|c|c|c|}
\hline & \multirow{2}{*}{\multicolumn{4}{|c|}{ Annual rate of growth ${ }^{1}$}} & \multicolumn{6}{|c|}{ Composition of bank credit ${ }^{2}$} \\
\hline & & & & & \multicolumn{2}{|c|}{ Housing } & \multicolumn{2}{|c|}{$\begin{array}{c}\text { Other } \\
\text { consumer }\end{array}$} & \multicolumn{2}{|c|}{ Business } \\
\hline & $2000-04$ & 2003 & 2004 & 2005 & 1999 & 2005 & 1999 & 2005 & 1999 & 2005 \\
\hline Indonesia & 9.1 & 13.0 & 19.0 & 24.5 & 5 & 8 & 7 & 30 & 34 & 48 \\
\hline Korea $^{3}$ & 9.0 & 5.3 & -1.6 & 1.5 & 9 & $33^{1}$ & 18 & 17 & 69 & 47 \\
\hline Malaysia & 7.9 & 3.1 & 25.0 & 12.2 & 18 & 28 & 8 & 16 & 64 & 45 \\
\hline Philippines & -0.4 & 2.8 & 0.4 & -1.3 & & & & & & 55 \\
\hline Thailand & -1.7 & 4.7 & 2.7 & 0.6 & 7 & 12 & 3 & $7^{4}$ & 71 & 62 \\
\hline
\end{tabular}


Table 4

Changes in the structure of the banking industry

\begin{tabular}{|c|c|c|c|c|c|c|c|c|}
\hline & \multicolumn{4}{|c|}{ Mergers and acquisitions ${ }^{1}$} & \multicolumn{2}{|c|}{ Concentration $^{2}$} & \multicolumn{2}{|c|}{$\begin{array}{c}\text { Share of } \\
\text { foreign-owned } \\
\text { banks }^{3}\end{array}$} \\
\hline & \multicolumn{2}{|c|}{ Domestic only } & \multicolumn{2}{|c|}{$\begin{array}{l}\text { Domesticl } \\
\text { foreign }\end{array}$} & \multirow{2}{*}{$\begin{array}{c}\text { End } \\
1998 \\
\text { No }\end{array}$} & \multirow{2}{*}{$\begin{array}{c}\text { End } \\
2004\end{array}$} & \multirow{2}{*}{$\begin{array}{c}1990 \\
\text { No }\end{array}$} & \multirow{2}{*}{$\begin{array}{l}2004 \\
\text { Value }\end{array}$} \\
\hline & No & Value & No & Value & & & & \\
\hline Indonesia & 1 & & & & 29.0 & 59.1 & $7.7^{4}$ & 12.8 \\
\hline Korea & 15 & 37.0 & 3 & 4.8 & 27.0 & 48.6 & 4 & 8 \\
\hline Malaysia & 17 & 0.0 & - & - & 54.3 & 70.7 & & 18.0 \\
\hline Philippines & 11 & 23.3 & 3 & 0.3 & 41.6 & 51.5 & $6.2^{5}$ & 13.8 \\
\hline Thailand & 3 & 75.7 & 4 & 10.0 & 51.5 & 69.0 & 5 & 18.0 \\
\hline
\end{tabular}

${ }^{1}$ In the commercial banking sector. Value in billions of dollars. ${ }^{2}$ Five largest banks' assets as $\%$ of total assets. For Korea, the share of the top 3 banks. ${ }^{3}$ As a \% of total assets. ${ }^{4} 1996 .{ }^{5}$ End-1995.

Sources: Mihaljek (2006), Fitch and central banks. 
Table 5

Commercial bank privatisations, 2000-05

\begin{tabular}{|c|c|c|c|c|}
\hline \multirow{2}{*}{$\begin{array}{c}\text { Country } \\
\text { Indonesia }\end{array}$} & \multirow{2}{*}{$\begin{array}{l}\begin{array}{c}\text { Number and main } \\
\text { characteristics of privatised } \\
\text { banks }\end{array} \\
15 \text { banks, accounting for } 70 \% \text { of } \\
\text { total assets, sold in IPOs }\end{array}$} & \multicolumn{2}{|c|}{ Guarantees extended } & \multirow{2}{*}{\begin{tabular}{l}
\multicolumn{1}{c}{$\begin{array}{c}\text { Residual state } \\
\text { ownership }\end{array}$} \\
Minority ownership in \\
a number of banks; to \\
be sold
\end{tabular}} \\
\hline & & Yes & $\begin{array}{l}\text { Guarantees to } \\
\text { depositors; gradually } \\
\text { reduced }\end{array}$ & \\
\hline Korea & $\begin{array}{l}4 \text { banks nationalised during 1997- } \\
98 \text { crisis sold through private } \\
\text { placement, tender and auction }\end{array}$ & Yes & $\begin{array}{l}\text { Deposits; bad loans; } \\
\text { contingent liabilities } \\
\text { (subject to limit; none } \\
\text { in some cases) }\end{array}$ & $\begin{array}{l}\text { Plan to sell } 32 \% \text { in } \\
\text { one major bank; } \\
\text { privatise holding } \\
\text { company with } 4 \text { state } \\
\text { bank subsidiaries }\end{array}$ \\
\hline Thailand & $\begin{array}{l}7 \text { banks taken over during } 1997- \\
98 \text { crisis; } 2 \text { sold through public } \\
\text { offering to strategic foreign } \\
\text { partners; } 2 \text { merged and } \\
\text { another bank partially sold by } \\
\text { public offering }\end{array}$ & Yes & $\begin{array}{l}\text { Limited compensation } \\
\text { for NPL losses }\end{array}$ & $\begin{array}{l}\text { Holdings (incl } \\
\text { majority) to be sold } \\
\text { eventually }\end{array}$ \\
\hline
\end{tabular}

Note: There were no privatisations in the Philippines.

Source: Mihaljek (2006), reporting on central bank answers to BIS questionnaire. 
Table 6

Lending to developing Asia by BIS reporting banks ${ }^{1}$

$\$$ billion

\begin{tabular}{|c|c|c|c|c|}
\hline & 1985 & 1995 & 2000 & 2006 Q2 \\
\hline Total & 108.0 & 363.5 & 341.4 & 744.3 \\
\hline \multicolumn{5}{|c|}{ A. By nationality of lending bank } \\
\hline US & 32.9 & 64.2 & 69.5 & 152.6 \\
\hline Japan & 33.9 & 134.6 & 72.0 & 90.1 \\
\hline Europe & 37.3 & 159.8 & 194.0 & 492.8 \\
\hline \multicolumn{5}{|c|}{ B. International versus local ${ }^{2}$} \\
\hline International & 93.6 & 307.1 & 238.7 & 426.9 \\
\hline Local & 14.4 & 56.4 & 102.8 & 317.4 \\
\hline \multicolumn{5}{|c|}{ C. Bank versus non-bank borrower ${ }^{3}$} \\
\hline Bank & 28.4 & 133.5 & 73.6 & 157.9 \\
\hline Non-bank & 65.3 & 173.6 & 165.2 & 269.0 \\
\hline \multicolumn{5}{|c|}{ D. By country of borrower } \\
\hline Korea & 31.4 & 85.8 & 70.6 & 246.4 \\
\hline Indonesia & 14.8 & 48.1 & 40.7 & 39.3 \\
\hline Malaysia & 12.0 & 21.0 & 37.1 & 60.9 \\
\hline Philippines & 13.8 & 9.7 & 19.1 & 24.3 \\
\hline Thailand & 7.9 & 68.3 & 35.6 & 38.6 \\
\hline
\end{tabular}

${ }^{1}$ Excluding reporting by Australia, Hong Kong and Singapore. 2 International claims are cross-border loans plus loans in foreign currency; local loans are made through local affiliates in local currency. ${ }^{3}$ This decomposition is available only for international claims.

Source: BIS International Consolidated Banking Statistics. 
Table 8

Pass-through from money market to domestic loan interest rates

Cumulative response of loan rate to a 1 percentage point rise in the money market rate after 1 and 12 months

\begin{tabular}{l|r|r|r|r}
\hline & \multicolumn{2}{|c|}{$1998-02$} & $\mathbf{2}$ & $\mathbf{1}$ \\
\hline & $\mathbf{1}$ & $\mathbf{1 2}$ & 006 \\
\hline Indonesia & 0.16 & 0.88 & 0.12 & 0.35 \\
Korea & 0.0 & -0.08 & 0.34 & 0.65 \\
Malaysia & -0.04 & 0.31 & 0.24 & 0.78 \\
Philippines & 0.23 & 0.46 & 0.34 & 0.84 \\
Thailand & 0.24 & 1.09 & 0.46 \\
Memorandum: & 0.91 & 1.07 & 1.00 & 1.00 \\
$\quad$ Australia & &
\end{tabular}

(2006) 
Table 9

Profits and risk-adjusted capital ratios

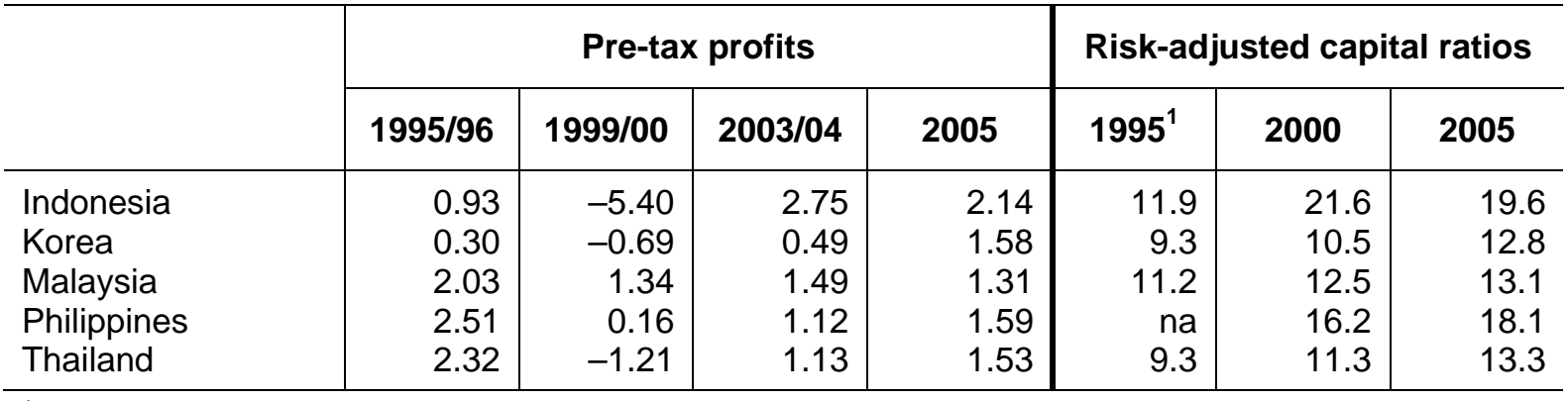

11995 estimates are given in Table 4 of Goldstein and Turner (1996) and, to the extent that inadequate provision had been made for impaired loans, can be regarded as overestimates of the true size of bank capital.

Note: Banks included are those whose total assets are greater than $\$ 1$ billion and for which profit data are available.

Sources: IMF Global Financial Stability Report and Fitch Ratings Bankscope. 
Table 10

The quality of bank loans

\begin{tabular}{|c|c|c|c|c|}
\hline & \multicolumn{2}{|c|}{ NPLs as \% loans } & \multicolumn{2}{|c|}{ Provisions as \% NPLs } \\
\hline & Peak & 2005 & 1998 & 2005 \\
\hline Indonesia & 48.6 (1998) & 15.6 & 28.6 & 39.5 \\
\hline Korea & 11.3 (1999) & 1.2 & $52.1(2000)$ & na \\
\hline Malaysia & 13.6 (1998) & 9.9 & 21.6 & 41.6 \\
\hline Philippines & 27.7 (2001) & 20.0 & 38.3 & 39.2 \\
\hline Thailand & 42.9 (1998) & 8.2 & 22.5 & 69.8 \\
\hline
\end{tabular}

Sources: IMF Global Financial Stability Report, March 2003 (for period 1997-2000) and GFSR, April 2006. Note that the criteria used to define NPLs have changed over time. 
Table 11

Operating costs and net interest margins ${ }^{1}$

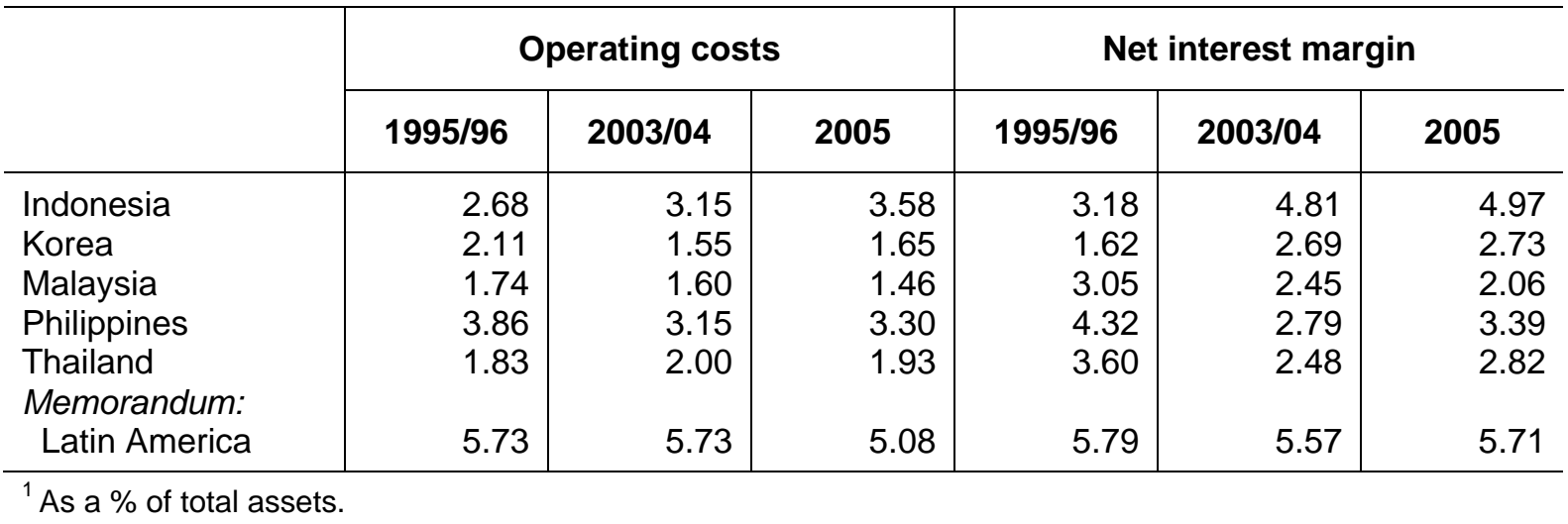


Table 12

Sensitivity of bank profits to cyclical conditions from 1996 to 2005

\begin{tabular}{|c|c|c|c|c|}
\hline & Yield spread $^{1}$ & $\begin{array}{c}\text { Real } \\
\text { one-month } \\
\text { interest rate }\end{array}$ & Growth rate ${ }^{2}$ & $\mathbf{R}^{2}$ \\
\hline 4 Asian countries [284] & $\begin{array}{r}-21.2 \\
(3.6)\end{array}$ & $\begin{array}{r}-25.7 \\
(4.6)\end{array}$ & $\begin{array}{r}22.8 \\
(14.8)\end{array}$ & 0.58 \\
\hline Korea [68] & $\begin{array}{r}-29.2 \\
(2.0)\end{array}$ & $\begin{array}{r}-33.9 \\
(3.6)\end{array}$ & $\begin{array}{l}28.5 \\
(3.2)\end{array}$ & 0.52 \\
\hline Malaysia [111] & $\begin{array}{r}1.1 \\
(0.9)\end{array}$ & $\begin{array}{l}-3.6 \\
(0.6)\end{array}$ & $\begin{array}{l}12.4 \\
(7.7)\end{array}$ & 0.55 \\
\hline Philippines [39] & $\begin{array}{r}-25.7 \\
(1.6)\end{array}$ & $\begin{array}{r}-15.3 \\
(2.9)\end{array}$ & $\begin{array}{r}7.4 \\
(0.6)\end{array}$ & 0.72 \\
\hline Thailand [65] & $\begin{array}{r}-50.5 \\
(3.6)\end{array}$ & $\begin{array}{r}-17.2 \\
(1.7)\end{array}$ & $\begin{array}{r}49.4 \\
(9.8)\end{array}$ & 0.60 \\
\hline Latin America [104] & $\begin{array}{r}4.7 \\
(1.3)\end{array}$ & $\begin{array}{r}1.0 \\
(0.6)\end{array}$ & $\begin{array}{r}6.7 \\
(2.5)\end{array}$ & 0.66 \\
\hline Central Europe [78] & $\begin{array}{r}-13.2 \\
(1.1)\end{array}$ & $\begin{array}{l}-6.5 \\
(0.4)\end{array}$ & $\begin{array}{l}40.3 \\
(3.2)\end{array}$ & 0.49 \\
\hline
\end{tabular}

${ }^{1}$ Benchmark long-term bond minus the one-month yield. ${ }^{2}$ Average of growth rate in current and previous year.

Note: t-statistics are given in round brackets under the estimated coefficient. The number of observations is shown in square brackets next to the country. A variable to control for the loan/total asset ratio was also included.

Sources: Fitch Ratings and BIS calculations. 
Table 13

\section{Bank share prices}

\begin{tabular}{l}
\hline \\
\cline { 2 - 8 }
\end{tabular}


Table 14

The credit ratings of banks

\begin{tabular}{l|r|r|r|r|r}
\hline \multirow{2}{*}{} & \multicolumn{2}{|c|}{ Moody's Bank Financial Strength Ratings } & \multicolumn{2}{c}{ Fitch Individual Ratings $^{2}$} \\
\cline { 2 - 6 } & \multicolumn{1}{|c|}{ Mar 1997 } & Dec 1998 & Dec 2005 & Dec 1998 & Dec 2005 \\
\hline Indonesia & D- to D (12) & E (11) & E to E + (9) & E (3) & D to C/D (12) \\
Korea & D (18) & E+ to D- (19) & D to D (15) & E to D/E (8) & C to B/C (12) \\
Malaysia & C to C+ (2) & D- (5) & D+ to C- (11) & D/E to D (6) & C/D (12) \\
Philippines & D to C/D (5) & D to D+ (11) & D- to D (11) & D to C/D (5) & D to C/D (13) \\
Thailand & D+ (10) & E to E+ (10) & D- to D (10) & E to D/E (12) & C/D (10) \\
Memorandum: & & & C & & \\
$\quad$ Germany & C+ to B- (29) & C to C+ (35) & C- to C (43) & D to C/D (21) & C/D to C (65) \\
\hline
\end{tabular}

${ }^{1}$ The Bank Financial Strength Rating is Moody's assessment of whether a bank is likely to require financial support from shareholders, the government or other institutions. The ratings range from $A$ (highest) to $E$ (lowest). ${ }^{2}$ January 1996. ${ }^{3}$ Individual Ratings represent Fitch's view on the likelihood that a bank would run into significant difficulties such that it would require support. The ratings have nine different gradations ranging from A (highest) to $E$ (lowest).

Sources: Moody's Investors Services and Fitch Bankscope; BIS calculations. 
Table 15

Forward-looking assessment of financial stability risks

\begin{tabular}{|c|c|c|}
\hline Risks & Indonesia & Korea \\
\hline Credit & $\begin{array}{l}\text { Repayment capacity of borrowers will } \\
\text { weaken in the wake of higher energy } \\
\text { prices. Explicit stress test of impact of fuel } \\
\text { price increase on credit risk. }\end{array}$ & $\begin{array}{l}\text { The maximum loan to value ratios for } \\
\text { housing loans kept comparatively low ( } 40 \\
\text { to } 60 \% \text { ) but housing loans mostly at } \\
\text { floating rate to heavily-indebted } \\
\text { households may face a heavy burden in } \\
\text { the event of an interest rate rise. }\end{array}$ \\
\hline Market & $\begin{array}{l}\text { Stress tests reported of impact of bond } \\
\text { price declines, currency depreciation and } \\
\text { changes in the policy rate on banks' capital } \\
\text { asset ratios. }\end{array}$ & $\begin{array}{l}\text { Significant market risk from banks' } \\
\text { holdings of bonds. Currency exposures } \\
\text { from substantial foreign currency assets of } \\
\text { commercial banks, and discussion of } \\
\text { banks' use of derivative products to } \\
\text { manage market risks. }\end{array}$ \\
\hline Liquidity & $\begin{array}{l}\text { Banks' heavy dependence on short-term } \\
\text { funding creates some liquidity risks. }\end{array}$ & $\begin{array}{l}\text { Statistics on maturity structure of assets } \\
\text { and liabilities and split between fixed- and } \\
\text { floating-rate debt. }\end{array}$ \\
\hline \multicolumn{3}{|c|}{ Sources: Bank Indonesia (2006) and Bank of Korea (2005). } \\
\hline
\end{tabular}


Table 16

Bankruptcy costs and legal rights in 2004

\begin{tabular}{l|c|c|c}
\hline & Lenders' legal \\
rights index & \multicolumn{2}{|c}{ Costs of } \\
& $\begin{array}{c}\text { Contract enforcement } \\
\text { (\% of debt) }\end{array}$ & $\begin{array}{c}\text { Bankruptcy costs } \\
\text { (\% of estate) }\end{array}$ \\
\hline Asia & 5 & 22 & 17 \\
of which: & 6 & 5 & 4 \\
Korea & 8 & 20 & 18 \\
Malaysia & 5 & 13 & 38 \\
Thailand & 3 & 16 & 13 \\
Latin America & 7 & 9 & 7 \\
Mature markets & & & \\
\hline
\end{tabular}

${ }^{1}$ The index measures the degree to which collateral and bankruptcy laws facilitate lending. The index ranges from 0 to 10, with higher scores indicating that collateral and bankruptcy laws are better designed to expand access to credit. This is the case when secured creditors are able to seize their collateral when a debtor enters reorganisation.

Sources: IMF Global Financial Stability Report (April 2005) (Table 4.3 in Ch IV Corporate finance in emerging markets) based on World Bank database. Financial Sector Development Indicators. 